\title{
The response of some spring barley cultivars grown in Finland to air-borne secondary infection by Bipolaris sorokiniana
}

\author{
AARNE KURPPA \\ Department of Plant Pathology, University of Helsinki* \\ SF-00710 HELSINKI 71, Finland
}

\begin{abstract}
Air-borne secondary inoculum of Bipolaris sorokiniana caused severe foliar diseases and yield losses in all 12 spring barley cultivars tested in greenhouses or in the field. For secondary infection to occur a high relative humidity was necessary. Yield losses due to foliar diseases reached a maximum of $43.4 \%$ in greenhouse experiments and $27.8 \%$ in the field. The mean losses were $20.3 \%$ and $12.3 \%$, respectively. Early infection at the time of heading or shortly after it resulted in higher yield losses than did later infection, although the symptom expression was opposite. Spore inoculation or natural secondary infection by the spores from a diseased crop after heading always resulted in a high infection incidence in the grain. Infection incidence as well as fungal invasion of the internal cell leyers of the grains varied significantly among barley cultivars. The most susceptible of those tested were cvs. Teemu, Paavo and Pomo, while the most resistant were Ingrid, Otra and Pirkka.
\end{abstract}

\section{Introduction}

Bipolaris sorokiniana (Sacc. in Sorok.) Shoem. (syn. Helminthosporium sativum Pamm., King \& Bakke), perfect state Cochliobolus sativus (Ito \& Kurib.) has a world-wide distribution as a major pathogen of cereals (SPRAQUE 1950). Yield losses in barley of higher than 10 per cent have been reported recently by PIENING (1973) and STACK (1982). In addition the fungus has been found to be

* Present address: Agricultural Research Centre, Department of Plant Pathology SF-31600 JOKIOINEN, Finland increasingly common in barley in the cool climate in North-Western Europe (JøRGENSEN 1974, Hewett 1975, Mä́elä 1975, KuRPPA 1984).

Conidia of the fungus are the main sources of infection, and are able to survive at least two years in soil (Ledingham 1970). Infection caused by spore liberation from plant debris is strongly related to the previous crop in the field (ChinN 1976, ReIs \& Wúnsche 1984). Important sources for spore liberation also include basal stems, lower leaves and subcrown intenodes of diseased host plants (MEAd 1942, ChInN 1977). Conditions for

Index words: Bipolaris sorokiniana, Helminthosporium sativum, Cochliobolus sativus, barley diseases, leaf blotch, headblight 
the occurrence of secondary infection of barley are most favourable during the late growing season, when crops are nearly ripe and relative humidity is high for at least part of the day (SPURR \& KiesLing 1961, CHULKINA 1972). Air-borne secondary infection may result in leaf spots and blotches, and headblight as well as infection in ripening seeds (MeAd 1942, Vendrig 1956).

\section{Materials and methods}

Experiments to study the response of barley cultivars to secondary infection of $\mathrm{B}$. sorokiniana were conducted mainly in greenhouses, but one field experiments was done as well. Additional interests of the study were the significance of the barley developmental stage at the time of infection as well as the role of the fungus isolate in inducing infection and foliar disease.

The seeds used for sowing in the experiments were all dressed with organomercurial seed dressing powder, $2 \mathrm{~g} / \mathrm{kg}$. In greenhouse experiments $25 \times 25 \mathrm{~cm}$ pots filled with non-sterile fertilized loamy field soil were sown to obtain at least 50 normally developed seedlings per pot. Approximately three weeks after sowing excess plants were rogued to leave 35 or 50 seedlings. For watering an equal volume of water was added to each pot. Extra fertilizer (N-P-K, containing essencial microelements) was given twice at seedling stages during watering. The field experiment was sown in treatment blocks with plot sizes of $6.65 \mathrm{~m}^{2}$, each block consisting of four cultivars and four replicates. The blocks were separated from each other with a belt of oats three meters wide, to prevent spore carry-over during spraying and short distance contamination later from the treated blocks.

The fungus isolates used for spore inoculum had the following origins:

A leaves six-row barley cv. unknown Keitele, Central Finland

B leaves two-row barley cv. Karri Lapinjärvi, Southern Finland
C leaves spring wheat cv. unknown Loimaa, Southern Finland

D seed six-row barley cv. Pomo

Helsinki, Southern Finland

E seed oats cv. Hannes

Maaninka, Central Finland

7550 seed two-row barley cv. Birgitta

Hämeenlinna, Southern Finland

The inoculum was prepared from fungal colonies grown three weeks on potato dextrose agar (PDA) in petri dishes at $22^{\circ} \mathrm{C}$, by homogenizing in distilled water to make a suspension containing c. $10^{4}$ spores $/ \mathrm{ml}$ (see ANDERSON \& BANTTARI 1976). Barley was sprayed with $10 \mathrm{ml} /$ pot in greenhouse experiments and $94 \mathrm{ml} / \mathrm{m}^{2}$ in the field. After this treatment the pots were incubated for 48 hours in a plastic tent with a relative humidity of $90-100 \quad \%$ and temperature of $16-22^{\circ} \mathrm{C}$. After incubation the barley was grown in a greenhouse or an opensided greenhouse. The barley in the field experiment was sprayed late in the evening when the natural relative humidity was high.

Three to twelve barley cultivars were inoculated simultaneously at 2 to 5 different stages of growth to determine the effect of the developmental stage of the crops on their response to air-borne infection. In pot experiments the first spraying was always done just before the time of heading, the second at early heading stage and the rest at 5 to 10-day intervals after that. In the field barley was sprayed with the spore suspension either a week before or two weeks after heading.

Five fungus isolates were studied for differences in symptom appearance and severity. Foliar symptoms were observed and recorded in all experiments 7 days after treatment. The leaf area showing lesions or total destruction was estimated using a key published by BRÖNNIMANN (1968) to estimate foliar disease caused by Septoria nodorum Berk. Symptoms were observed, however, until the full ripening of the grain. Harvested grain yields were drained and weighed and samples from them were analyzed for the incidence 
and localization of $B$. sorokiniana in the seeds as described by KurPPA (1984). Samples of grain yields from the field experiment were also analyzed for germination of the seeds.

To test the significance of the data, analysis of variances and t-test were used.

\section{Results}

Foliar symptom incidence and severity due to secondary infection of Bipolaris sorokiniana varied depending on the fungus isolate and barley cultivar. One isolate induced dark brown oval discrete spots while the others also caused leaf blotch, typical of the fungus (Fig. 3). In these preliminary studies, cv.
Table 1. Leaf area damaged by Bipolaris sorokiniana.

\begin{tabular}{lcccc}
\hline \multirow{2}{*}{$\begin{array}{l}\text { Fungus } \\
\text { isolate }\end{array}$} & \multicolumn{3}{c}{ Barley cultivar } & \\
\cline { 2 - 4 } & Karri & Paavo & Pomo & Mean \\
\hline $\mathrm{A}^{1}$ & $17.5^{*}$ & 10.0 & 10.0 & 12.5 \\
$\mathrm{~B}$ & 37.5 & 37.5 & 37.5 & 37.5 \\
$\mathrm{C}$ & 17.5 & 62.5 & 25.0 & 35.0 \\
$\mathrm{D}$ & 50.0 & 75.0 & 50.0 & 58.3 \\
$\mathrm{E}$ & 25.0 & 37.5 & 25.0 & 29.2 \\
\hline
\end{tabular}

For fungus isolate see text

* Per cent damaged leaf area as recorded 7 days after spraying the young non-heading barley with fungal suspension

F-values: Fungus isolates $=7.1^{x}, \operatorname{LSD}_{t 0.05}=12.3 \%$ Cultivars $\quad 4.7^{\times}=14.1 \%$

Paavo was found to be extremely susceptible to secondary infection (Table 1.). The fungus was capable of causing severe foliar in-

Table 2. The effect of crop developmental stage on destroyed leaf area and grain yield in different barley cultivars, due to infection by Bipolaris sorokiniana applied at various intervals.

\begin{tabular}{|c|c|c|c|c|c|c|c|c|}
\hline \multirow[t]{3}{*}{ Cultivar } & \multicolumn{6}{|c|}{ Time of spraying } & \multirow{2}{*}{\multicolumn{2}{|c|}{ Mean w/o control }} \\
\hline & \multicolumn{2}{|c|}{$\mathrm{I}^{1}$} & \multicolumn{2}{|c|}{ II } & \multicolumn{2}{|c|}{ III } & & \\
\hline & DLA* & $\mathrm{Y}$ & DLA & $\mathrm{Y}$ & DLA & $\mathrm{Y}$ & DLA & $\mathrm{Y}$ \\
\hline Eero & 30 & 59.0 & 37 & 84.1 & 42 & 93.2 & 36.3 & 78.8 \\
\hline Etu & 20 & 80.2 & 30 & 84.6 & 42 & 89.1 & 30.7 & 85.2 \\
\hline Hјa-673 & 10 & 75.6 & 27 & 78.7 & 32 & 83.7 & 23.0 & 79.3 \\
\hline Ingrid & 20 & 76.3 & 32 & 95.0 & 37 & 89.3 & 29.7 & 86.9 \\
\hline Karri & 10 & 73.3 & 22 & 80.6 & 27 & 79.9 & 19.7 & 77.9 \\
\hline Otra & 10 & 81.0 & 22 & 96.0 & 27 & 92.4 & 19.7 & 89.8 \\
\hline Paavo & 40 & 64.0 & 42 & 68.7 & 47 & 88.2 & 43.0 & 73.6 \\
\hline Pomo & 20 & 69.2 & 37 & 72.2 & 42 & 72.8 & 33.0 & 71.4 \\
\hline Pirkka & 15 & 72.4 & 27 & 88.1 & 37 & 92.3 & 26.3 & 84.3 \\
\hline Suvi & 27 & 64.9 & 35 & 81.9 & 40 & 80.3 & 34.0 & 75.7 \\
\hline Tammi & 25 & 78.2 & 30 & 84.3 & 42 & 84.0 & 32.3 & 82.2 \\
\hline Teemu & 20 & 56.6 & 37 & 81.8 & 40 & 74.7 & 32.3 & 71.0 \\
\hline
\end{tabular}

$1 \mathbf{I}=$ c. one week before heading

II = 10 days after I

III $=20$ days after I

*DLA $=\%$ destroyed leaf area, recorded 7 days after the barley was sprayed with fungal suspension

$\mathrm{Y} \quad=$ relative grain yield

Fungal isolate used was 7550. After spraying the barley was grown in an open-sided glasshouse. Controls for each cultivar were 0.0 (destroyed leaf area) or 100.0 (relative grain yield).

F-values: Grain yield/treatment $=186.2^{\mathrm{x}}, \mathrm{LSD}_{10.05}=3.8 \%$

$$
-n-\text { cultivar }=15.2^{\mathrm{xx}}, \quad=9.5 \%
$$

T-values for treatment/yield:

$$
\begin{aligned}
\text { Control }-I & =12.4^{x x} \\
\text { Control }- \text { II } & =5.6^{x} \\
\text { Control }- \text { III } & =7.6^{x} \\
\text { I }- \text { II } & =3.5^{x} \\
\text { I }- \text { III } & =4.4^{x} \\
\text { II }- \text { III } & =0.6
\end{aligned}
$$




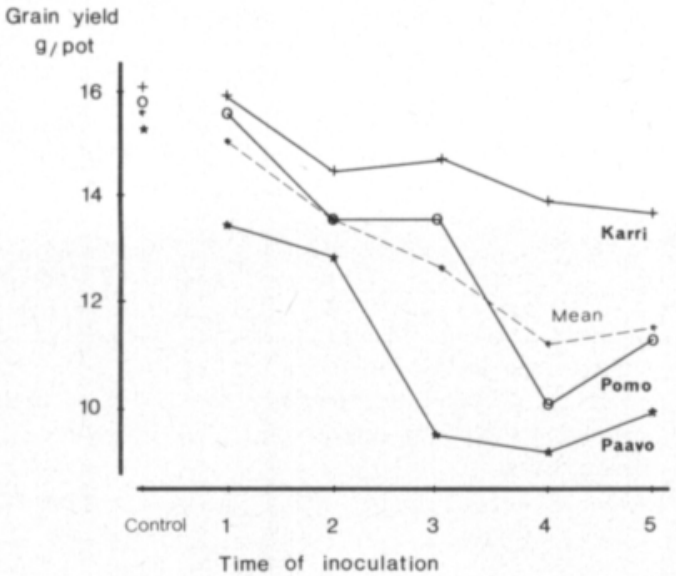

Fig. 1. The effect of barley developmental stage and cultivar on the yield losses caused by Bipolaris sorokiniana sprayed onto the crop in greenhouse experiments. Fungus isolate $\mathrm{A}$ was used. Time of inoculation: 1 = seedling stage, $2=$ heading, $3-5=$ five day-intervals after heading. F-value: Time of inoculation = $18.4^{\mathrm{x}}, \mathrm{LSD}_{0.05}=8.5 \%$.

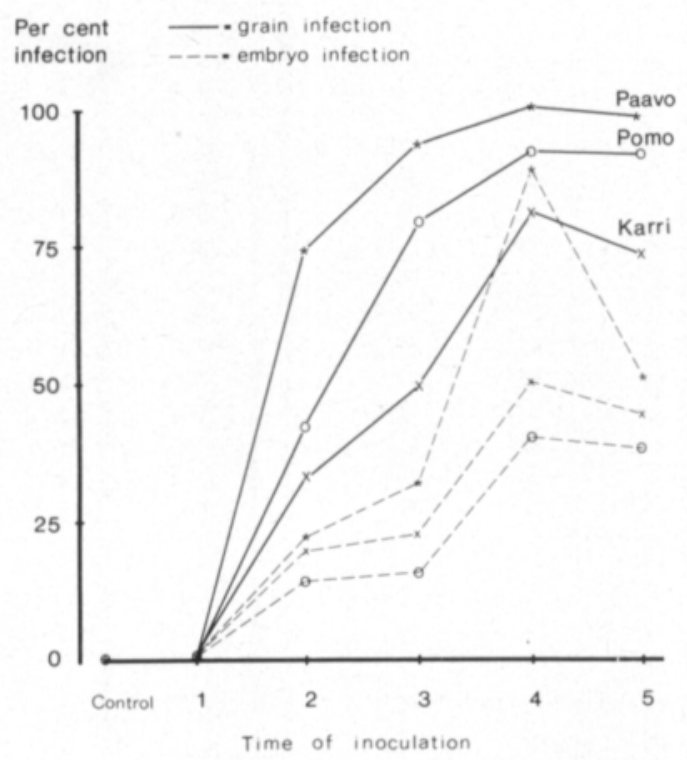

Fig. 2. The effect of barley developmental stage and cultivar on the incidence and severity of infection in grain yields caused by Bipolaris sorokiniana sprayed onto the crop in greenhouse experiments. For fungus isolate and inoculations see Fig. 1. F-values: Grain infection, time of inoculation $=62.0^{\mathrm{xx}}, \mathrm{LSD}_{0.05}=8.5 \%$, cultivar $=17.1^{\mathrm{xx}}, \mathrm{LSD}_{0.05}=10.0 \%$. Embryo infection, time of inoculation $=257.6^{\mathrm{x}}$, $\mathrm{LSD}_{0.05}$ $=3.6 \%$, cultivar $=27.6^{\mathrm{xx}}, \quad \operatorname{LSD}_{0.05}=7.9$ $\%$. fection even at the seedling stage if inoculation was followed by incubation of the seedlings 48 hours at $20^{\circ} \mathrm{C}$ and $90-100 \%$ relative humidity.

In greenhouse experiments barley developmental stage during infection was of great importance in disease severity and yield losses. Infection before heading or directly after it usually resulted in a lower percentage of foliar damage than if it occurred at a later stage (Table 2). Yield losses however, could be relatively high, even if not much assimilitive leaf area was lost (Fig. 1, Table 2). Secondary infection close to ripening had a less negative effect on the yield than earlier infections had; this was particularly true with early six-row cvs. Eero, Otra and Paavo. Late foliar infection still caused an average yield reduction of 15 per cent. The highest average yield reductions due to secondary infection were recorded with the cvs. Teemu (29.0\%), Pomo (28.6 \%) and Paavo (26.4 \%) and the lowest with the cvs. Otra (10.2\%) and Ingrid $(13.1 \%)$. Individual results varied with different developmental stages of barley, however (Table 2).

Inoculation of the crop before heading never resulted in a significantly high rate of infection of the grains in greenhouse experiments. (Fig. 2, Table 3). Spraying with the spore suspension at later developmental stages caused increasing incidences of seed infection. The highest per centage of infected seeds occurred when the crop was sprayed at the ripening stage. Infection at the embryos or inner cell layers in the seeds reached its highest occurrence shortly before the maximal incidence of seed infection (Fig. 2). Dramatic differences were found between the cultivars with respect to the incidence of seed infection and fungal invasion at the embryos. The highest rate of seed and embryo infection was found with the crs. Teemu, Paavo, Suvi, Etu and Tammi, and the lowest with cvs. Ingrid, Otra and Pirkka. Seeds of cv. Karri were not frequently infected but fungal invasion in the embryo of the seeds 
Table 3. The effect of developmental stage of different barley cultivars on the infection incidence of its grains and embryos due to Bipolaris sorokiniana applied at various intervals.

\begin{tabular}{|c|c|c|c|c|c|c|c|c|}
\hline \multirow[t]{3}{*}{ Cultivar } & \multicolumn{6}{|c|}{ Time of spraying } & & \\
\hline & \multicolumn{2}{|c|}{$I^{1}$} & \multicolumn{2}{|c|}{ II } & \multicolumn{2}{|c|}{ III } & \multicolumn{2}{|c|}{ Mean } \\
\hline & $\mathrm{IG}^{*}$ & IE & IG & IE & IG & IE & IG & IE \\
\hline Eero & 7.0 & 0.0 & 9.0 & 1.0 & 52.3 & 14.0 & 22.8 & 5.0 \\
\hline Etu & 0.7 & 0.0 & 18.7 & 2.0 & 76.0 & 27.0 & 31.8 & 9.7 \\
\hline Hјa-673 & 2.7 & 0.0 & 8.0 & 1.0 & 4.7 & 16.0 & 18.5 & 8.0 \\
\hline Ingrid & 2.0 & 0.0 & 4.7 & 0.0 & 26.7 & 7.0 & 11.1 & 2.3 \\
\hline Karri & 3.3 & 0.0 & 4.7 & 0.0 & 32.0 & 9.0 & 13.3 & 5.0 \\
\hline Otra & 1.0 & 0.0 & 2.7 & 0.0 & 30.7 & 15.0 & 11.5 & 3.0 \\
\hline Paavo & 2.7 & 0.0 & 19.3 & 4.0 & 70.0 & 44.0 & 30.6 & 16.0 \\
\hline Pomo & 0.7 & 0.0 & 10.3 & 2.0 & 47.3 & 21.0 & 19.4 & 7.7 \\
\hline Pirkka & 1.3 & 0.0 & 6.0 & 1.0 & 26.0 & 6.0 & 11.1 & 2.3 \\
\hline Suvi & 0.7 & 0.0 & 12.0 & 2.0 & 78.7 & 34.0 & 30.4 & 12.0 \\
\hline Tammi & 4.0 & 0.0 & 15.3 & 3.0 & 63.7 & 34.0 & 27.7 & 12.3 \\
\hline Teemu & 6.0 & 0.0 & 24.0 & 4.0 & 85.3 & 46.0 & 38.4 & 17.3 \\
\hline Mean & 2.7 & 0.0 & 11.1 & 1.7 & 52.8 & 22.7 & & \\
\hline
\end{tabular}

I I = c. one week before heading

* $\mathrm{IG}=$ infection incidence of the grains

II = 10 days after I

$\mathrm{IE}=$ infection incidence of the embryos

III $=20$ days after I

For details see table 2 .

F-values: Infection incidence (w/o controls) $/$ treatments $=289.7^{\mathrm{xx}}, \mathrm{LSD}_{10.05}=2.5 \%$

$$
-n-\quad \text { /cultivars }=41.9 \mathrm{x}, \quad=4.3 \%
$$

Infection incidence of the embryos/cultivars $=29.2^{\mathrm{xx}} \quad=4.4 \%$ (III only)

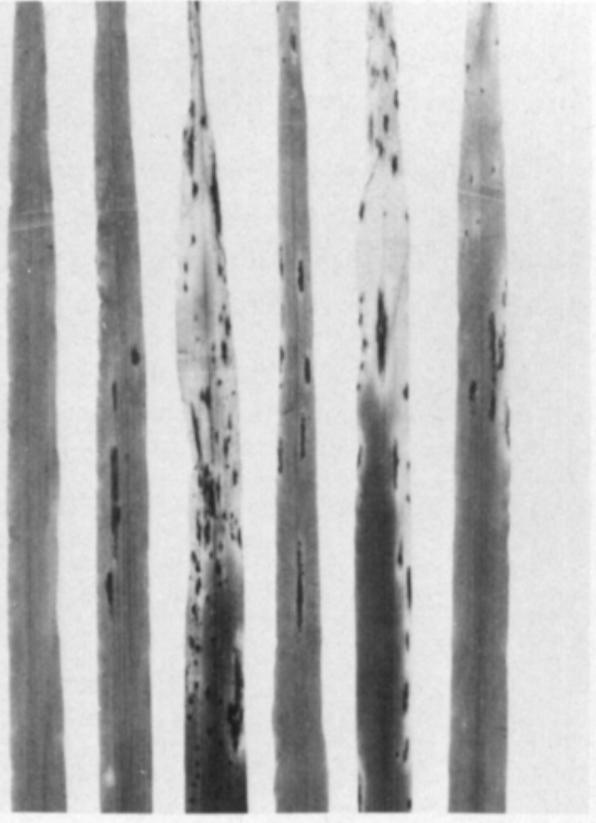

Fig. 3. Leaf symptoms caused by different isolates of Bipolaris sorokiniana in barley cultivar Paavo as observed 7 days after inoculation. Left to right: control and isolates $\mathrm{A} \rightarrow \mathrm{E}$.

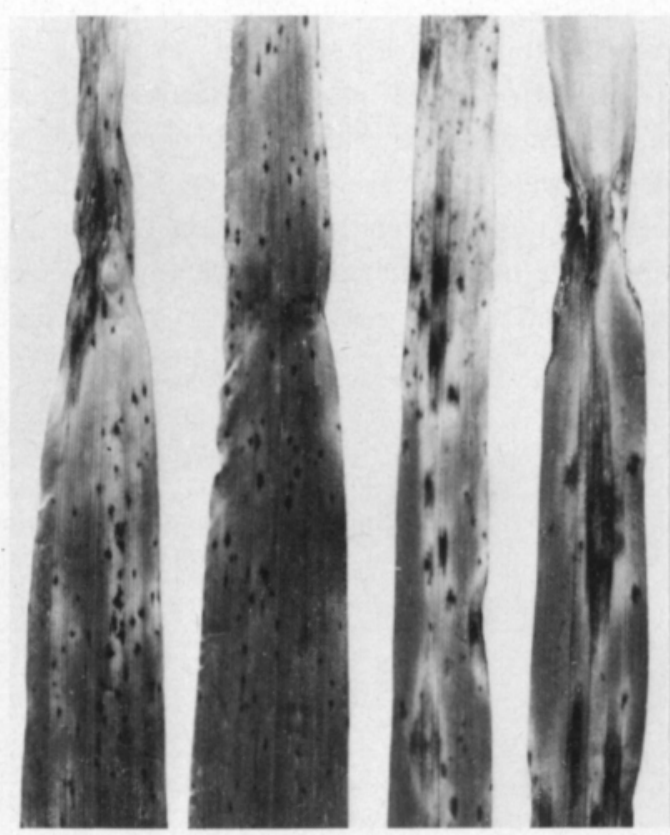

Fig. 4. Leaf spots and blotches caused by Bipolaris sorokiniana in a field experiments on barley cv. Pomo. On the left the symptoms as observed one week and on the right four weeks after inoculation. 
Table 4. The effect of the developmental stage of different barley cultivars on yield reduction due to Bipolaris sorokiniana applied to the field crop.

\begin{tabular}{lrrrrr}
\hline Treatment & \multicolumn{4}{c}{ Cultivar } & \\
\cline { 2 - 4 } & Ingrid & Karri & Otra & Pomo & Mean \\
\hline Control & $100.0^{*}$ & 100.0 & 100.0 & 100.0 & 100.0 \\
I' & 76.5 & 72.2 & 97.8 & 96.0 & 85.6 \\
II & 85.7 & 95.2 & 86.0 & 94.0 & 90.2 \\
\hline Mean w/o & & & & & \\
control & 81.1 & 83.7 & 91.9 & 95.0 & \\
\hline
\end{tabular}

I I = Sprayed c. one week before heading

II = Sprayed three weeks later

* Relative grain yield

was more severe than average (Fig. 2, Table 3). Some seed infection also occurred due to fungal growth and subsequent spore liberation from lower diseased leaves in the opensided glasshouse, but no invasion of the embryos was found.

In the field, spraying of the spore suspension on barley also resulted in a high incidence of foliar disease at the seedling stage. The fungus caused numerous leaf spots and blotches on all barley cultivars used in the experiment. The lesions grew rapidly larger, and natural sporulation was observed seven to ten days after spraying (Fig. 4). Similar leaf spot and blotch development followed a spraying treatment carried out three weeks later, and within one month no visible dif- ferences could be observed between the differentially treated plants. In addition to spotted and complitely damaged leaves, the fungus also affected the heads and remaining shoots resulting in increased lodging in the treated blocks. Both inoculations significantly decreased the grain yields of all barley cultivars studied, with the early spraying treatment having a greater effect (Table 4). In this experiment the highest yield losses occurred with two-row cultivars Ingrid and Karri, which were previously found to be relatively resistant in greenhouse experiments.

A low incidence of disease occurred in control blocks due to natural secondary infection by the fungus; however both spraying treatments resulted in a great increase of seed and embryo infection over the control (Table 5). The two treatments caused a relatively similar seed infection level, but embryo infection was much higher with later spraying than with earlier. Cultivar Karri showed higher susceptibility to fungal invasion in the embryos than did the other cultivars.

\section{Discussion}

The importance of Bipolaris sorokiniana as a foliar pathogen of barley is probably greater in North-Western Europe and Easter Canada than anywhere else. The high inci-

Table 5. The effect of the developmental stage of different barley cultivars on the infection incidence of its grain and embryos due to Bipolaris sorokiniana applied to the crop in a field experiment.

\begin{tabular}{|c|c|c|c|c|c|c|c|c|c|c|}
\hline \multirow[t]{2}{*}{ Treatment } & \multicolumn{5}{|c|}{$\begin{array}{l}\text { Infection incidence of the grains }(\%) \\
\text { Cultivar }\end{array}$} & \multicolumn{5}{|c|}{$\begin{array}{l}\text { Infection incidence of the embryos }(\%) \\
\text { Cultivar }\end{array}$} \\
\hline & Ingrid & Karri & Otra & Pomo & Mean & Ingrid & Karri & Otra & Pomo & Mean \\
\hline Control & 9.3 & 14.0 & 10.0 & 9.5 & 10.7 & 0.5 & 2.0 & 1.5 & 0.5 & 1.3 \\
\hline $\mathrm{I}^{1}$ & 55.7 & 83.5 & 55.3 & 58.7 & 63.8 & 10.5 & 16.5 & 2.5 & 9.5 & 9.8 \\
\hline II & 63.2 & 84.3 & 78.3 & 66.7 & 73.1 & 16.0 & 35.5 & 16.5 & 16.0 & 21.0 \\
\hline
\end{tabular}

I $\quad$ I = Sprayed c. one week before heading

II = Sprayed three weeks after I

Fungal isolate used was A.

F-values: Infection incidence of the grains /treatment $=819.2^{\mathrm{xx}}, \operatorname{LSD}_{10.05}=4.0 \%$

$-"-\quad$ /cultivar $=22.3^{\mathrm{xx}}, \quad=4.1 \%$

Infection incidence of the embryos/treatment $=274.0^{\mathrm{xx}}, \quad=2.1 \%$

$$
-n-\quad / \text { cultivar }=19.3^{\mathrm{xx}}, \quad=5.6 \%
$$


dence of the fungus and its severe disease symptoms as reported by LANGE de la CAMP (1969), Smedegard-Petersen (1972), Hewett (1975), MĀKelä (1975) and Clark (1978) should have drawn attention to the need for further studies of secondary infection by the fungus. However, only a few reports are available concerning direct damage to barley caused by air-borne secondary infection of the fungus.

Differences in susceptibility among barley cultivars and in the pathogenicity of the fungus isolates have been observed by CLARK (1957) and GAYED (1962) but variability in foliar symptoms has not been stressed. Although the degree of leaf damage has a strong effect on grain yield, the time of leaf senescence is also of major importance. Relatively early infection may result in severe losses in grain yield and quality as MEAD (1942) and VendRIG (1956) have reported.

In this study results of individual greenhouse experiments showed considerable variation but the characteristic reaction of a cultivar to the fungus remained unchanged. The same cultivars were previously shown by KuRPPA $(1984,1985$ a.) to have a corresponding reaction to soil-borne inoculum and incidence of seed-borne infection.

Barley inoculation at seedling stage before heading resulted in dramatic yield losses, which were probably a result of continuous damage due to long-lasting fungal growth on the leaves. Experimental inoculation of the plants by spraying resulted in much earlier spore liberation than is usual, causing considerable secondary infection. Couture and SutTon (1978) observed heavy sporulation beginning in early July from plant debris and primarily infected crops. However, they also reported that at times a few spores were dispersed sufficiently early in the growing season to serve as inoculum in epidemics.

The grain of all cultivars became severely infected by the fungus, if the crop was sprayed with the spore suspension after the time of heading. As was also found by ANDERSON and BANTTARI (1976) the infection often was more than superficial even in the resistant cultivars. Low fungal invasion of the inner leyers of the grains rather than low infection incidence of the grains themselves is a feature of varietal resistance to the fungus.

In the field, spraying the spore suspension on barley before heading resulted in rapid growth and natural sporulation of the fungus due to favourable weather conditions. Two-row cultivars Ingrid and Karri, previously found to be relatively resistant to the fungus, suffered from heavy lodging, which was at least partially related to foliar disease. A high level of seed infection resulted due to persistent head wetness during lodging. The data for yield losses and seed infection from the plots sprayed with spore suspension would probably have been less outstanding, if lodging had not taken place. Fungal invasion of the inner grain was sufficiently severe to cause a significant reduction in the value of the yield as sowing seed. Such internal damage was found to be widespread in a survey of commercial barley seed by KURPPA (1984).

Acknowledgements. I am grateful to Ms. Jennifer Shier for revision of the English manuscript.

\section{References}

Anderson, W.H. \& Banttari, E.E. 1976. The effect of Bipolaris sorokiniana on yield, kernel weight and kernel discoloration in six-row spring barleys. Pl. Dis. Reptr, 60: 754-758.
Bronnimann, A. 1968. Zur Kenntnis von Septoria nodorum Berk; dem Erreger der Spelzenbrăune und einer Blattdürre des Weizens. Phytopath. Z. 61: 101-146. 
ChInN, S.H.F. 1976. Cochliobolus sativus conidia populations in soils following various cereal crops. Phytopath. 66: 1082-1084.

,- 1977 . Influence of fungicide sprays on sporulation of Cochliobolus sativus on Cypress wheat and on conidial populations in soil. Phytopath. 67: 133-138.

Chulkina, V.A. 1972. Soil infestation and some methods for its suppression in the control of common root rot of barley. A translation of Mikologiya i fitopatologiya 6: 435-439.

Clark, R.V. 1957. The evaluation of variability in pathogenicity of Helminthosporium sativum and the relation temperature to disease development on barley. Diss. Abstr. 17: 220-221.

- , 1978. Distribution and severity of root and leaf diseases and cereal leaf beetle damage of barley in Western Ontario. Can. Pl. Dis. Surv. 58: 33-38.

Couture, L. \& Sutron, J.C. 1977. Relation of weather variables and host factors to incidence of airborne spores of Bipolaris sorokiniana. Can. J. Bot. 56: 2162-2170.

GAYED, S.K. 1962. The pathogenicity of six strains of Helminthosporium sativum to three cereals with special reference to barley. Mycopath. 18: 271-279.

Hewett, P.D. 1975. A health survey of barley. Pl. Path. 24: 229-232.

Jørgensen, J. 1974. Occurence and importance of seed borne inoculum of Cochliobolus sativus in Denmark. Acta Agric. Scand. 24: 49-54.

KurPPA, A. 1984. Bipolaris sorokiniana on barley seed in Finland. J. Agric. Sci. Finl. 56: 175-181.

,- 1985 a. Reaction of spring barley cultivars grown in Finland to soil-borne infection by Bipolaris sorokiniana and to its toxic metabilites. J. Agric. Sci. Finl. 57: 85-96.

LANGE de la CAMP, M. 1969. Zur Bedeutung von Helmin- thosporium sativum P., K. \& B. auf Sommergerste under mitteleuropäischen Verhältnissen. Arch. Pfl. Schutz. 5: 75-82.

LeDINGHAM, R.J. 1970. Survival of Cochliobolus sativus conidia in pure culture and in natural soil at different relative humidies. Can. J. Bot. 48: 1893-1896.

MEAD, H.W. 1942. Environmental relationship in a seed-borne disease of barley caused by Helminthosporium sativum Pammel, King \& Bakke. Can. J. Res. C, 20: $525-538$.

MÄKELĀ, K. 1975. Occurence of Helminthosporium species on cereals in Finland in 1971-1973. J. Sci. Agric. Soc. Finl. 47: 181-217.

PIEnING, L.J. 1973. Differential yield response of ten barley cultivars to common root rot. Can. J. Pl. Sci. 53: 763-764.

ReIS. E.R. \& WONSCHE, W.A. 1984. Sporulation of Cochliobolus sativus on residues of winter crops and its relationship to the increase of inoculum density in soil. Pl. Dis. 68: 411-412.

SMEDEGÁRD-PETERSEN, V. 1972. Rhyncosporium secalis, Cochliobolus sativus og Pyrenophora teres på bygg i Danmark. Nord. Jordbr. Forskn. 54: 72-74.

SPRaque, R. 1950. Disease of cereals and grasses in North America. 538 p. New York.

Spurr, H.W. \& Kiesling, R. 1961. Field and host studies of paratisism by Helminthosporium sorokinianum. Pl. Dis. Reptr, 45: 941-944.

Stack, R.W. 1982. Yield losses in spring barley due to common root rot in Eastern North Dakota. Phytopath. 72: 1139-1140.

VeNDRIG, J.G. 1956. De levenscyclus van Helminthosporium sativum P., K. \& B. ob tarve en gerst. Abs. in Tijschr. Pl. Ziekt. 62: 30 .

Ms received January 18, 1985 


\title{
SELOSTUS
}

\section{Suomessa viljeltyjen ohralajikkeiden \\ alttius Bipolaris sorokiniana-sienen \\ ilmalevintäisen kuromatartunnan aiheuttamalle lehtilaikkutaudille}

\author{
Aarne Kurppa \\ Helsingin yliopiston kasvipatologian laitos, \\ 00710 Helsinki $71^{*}$
}

Suomessa viljeltyjen ohralajikkeiden reagointia ilman mukana leviävän ohran tyvi- ja lehtilaikkua aiheuttavan Bipolaris sorokiniana-sienen (syn. Helminthosporium sativum, koteloaste Cochliobolus sativus) kuromatartuntaan tutkittiin astia- ja kenttăkokeiden avulla Helsingin yliopiston kasvipatologian laitoksella vuosina 1973-1979. Astiakokeita tehtiin normaalissa kasvihuoneessa ja katetussa ulkotilassa, missă ilman lämpötila ja kosteus săilyivăt lähellä vallinneita luontaisia arvoja. Kokeiden avulla pyrittiin lajikealttiuden lisăksi selvittämaaan ohran infektoitumisaikaisen kehitysvaiheen merkitystă sekă myös sienirodun vaikutusta taudin oireisiin ja ankaruuteen.

Sienen kuromasuspensio (noin $10^{4} \mathrm{kuromaa} / \mathrm{ml}$ ) levitettiin kasvustoihin sumuttamalla. Käsittelyaikoja oli astiakokeissa 3-5 ja kenttăkokeessa kaksi. Ensimmäinen käsittely tapahtui juuri ennen tăhkälletuloa ja seuraavat $5-10$ vuorokauden välein paitsi kenttäkokeessa, missă toinen sumutuskerta seurasi kolmen viikon kuluttua ensimmäisestä. Koeastiat, myös kontrollit, siirrettiin sumutuskäsittelyn jälkeen kahdeksi vuorokaudeksi muovitelttaan, minkä ilman suhteellista kosteutta pidettiin $90-100 \%$ :ssa ja lämpötilaa $16-22^{\circ} \mathrm{C}$ :ssa. Kenttäkokeen kasvustot sumutettiin myöhảän illalla. Oireet havainnoitiin ja tulostettiin 7 vrk:n kuluttua, mutta havainnointia jatkettiin kasvustojen tuleentumiseen asti. Korjatuista sadoista maăritettiin jyvien ulkoinen ja sisăinen sienitartunta, kenttäkokeen sadoista myös jyvien itåvyys sekă orastuvuus.

Ohrakasvustoihin sumutettu kuromasuspensio samoin kuin kenttăkokeessa todettu luontainen kuromalevintă aiheuttivat voimakkaita lehtilaikkuoireita kaikissa tutkittavina olleissa 12 ohralajikkeessa. Eri sieniisolaattien aiheuttamat oireet poikkesivat havaittavasti toisistaan, mutta oire-eroja aiheutui myös lajikkeiden erilaisesta reagoinnista. Lyhytaikainen kuromalevitystä seuraava kostea jakso todettiin vălttămăttömăksi sieniinfektion tapahtumiseksi.

Kasvuston infektoiminen ennen tähkälletuloa johti astiakokeissa lähinnă vain lehtilaikkujen muodostumiseen ja laikkuisten lehtien myöhempäăn kuihtumiseen. Kenttäkokeessa varhainenkin kuromasumutus aloitti sienen nopean kehittymisen ja luontaisen sekundäărisen kuromalevinnän kasvustossa, mikă myös johti jyvăsadon runsaaseen infektoitumiseen.

Lehdistön osittaisesta tuhoutumisesta seurasi astiakokeissa suurimmillaan $43.4 \%$ :n satotappio (lajike Teemu) ja kenttäkokeissa $27.8 \%$ :n tappio (Karri). Kokeiden keskiarvot olivat vastaavasti $20.3 \%$ ja $12.3 \%$. Ennen tăhkimistă puhjennut lievănäkin pysynyt lehtilaikkutauti aiheutti suuremman sadonmenetyksen kuin kolmisen viikkoa tăhkălletulon jälkeen puhjennut, voimakkaaksi kehittynyt lehdistön kuihtuminen.

Suoranaisen satotappion lisăksi jyvăsadon sienitartunta oli kokeissa merkittäväă. Tähkälletulon jälkeinen sieni-infektio johti astiakokeissa lajikkeesta riippuen 26-100 \%:n siementartuntaan. Luontainen kuromatartunta laikkutaudin kuihduttamista lehdistă johti 55$84 \%:$ :n siementartuntaan kenttäkokeessa. Lajike-erot ilmenivät suurina etenkin jyvien infektoituneisuusasteena ja sieni tunkeutui yleisesti suurinta alttiutta osoittaneiden lajikkeiden jyvien sisäosiin infektoiden myös alkion. Koetulosten yhteenvetona voitiin todeta lajikkeet Teemu, Paavo ja Pomo altteimmiksi sekä Ingrid, Otra ja Pirkka kestävimmiksi sienen sekundäări-infektiolle. Tutkittaessa aikaisemmin lajikkeiden reagointia maalevintăiseen sienitartuntaan päädyttiin samankaltaiseen jărjestykseen.

Sienen aiheuttamaa lehtilaikkutautia voidaan tarvittaessa torjua fungisidiruiskutusten avulla, mutta toimenpide ei ole useinkaan taloudellisesti kannattava, koska lehdistö kuihtuu tavallisesti vasta kasvun myöhăisessä vaiheessa. Torjunta vähentäă jyvăsadon sienitartuntaa, mutta ei pysty estämäăn sită kokonaan. Sopivan viljelykierron ja siemenen peittauksen avulla saavutetaan hyvă torjuntatulos, koska suuri osa sekundaaăriinfektiota aiheuttavista sienen kuromista on lăhtőisin itse kasvustosta tai edellisen kasvuston satojătteistă. Ohran lisăksi vehnă on sienelle erityisen altis. Kaura, öljykasvit, palkokasvit, juurikasvit sekä erāăt nurmikasvit ovat kestäviä ja soveltuvat siten hyvin viljelykiertoon keskeyttämään ohran tai vehnăn viljelyn ainakin kahden kasvukauden ajaksi.

* Nykyinen osoite:

Kasvitautiosasto, MTTK, 31600 Jokioinen 